\title{
The Attahashi Family: The Genealogy of the Ruler of Sungai Iyu in Aceh
}

\author{
Mehmet Özay
}

\begin{abstract}
The aim of this article is to present an analytical history of the Attahashi family of Turkish ancestry by illustrating its genealogy, whose members claim to be descendants of a Turkish ruler who is supposed to have arrived in Aceh in the late decades of the 16 th or beginning of the 17 th century. This attempt considers the connection to Sungai Iyu partly aligned with the eco-political developments in the 19th century and beginning of the 20th century. According to the argumentation of the current generation of the family, some individuals in the family became local rulers in Lam Kabeu and Sungai Iyu during the last century of the Sultanate of Aceh Darussalam. The relevant data, which sheds new light upon the traces of the Turkish existence in the region, has been acquired from various authentic written documents, oral information from various individuals including family members, and observations in field trips throughout the last decade. During the research, the author has put all his efforts to classify and comparatively examine the data from the various versions of relevant manuscripts, collected from Banda Aceh, Aceh Besar, Sungai Iyu and Medan, with each other.
\end{abstract}

Keywords: Attahashi, ghazi, Aceh, Sungai Iyu, Lam Kabeu.

Öz: Bu makalede, Açe'deki bir Türk kökenli ailenin analitik tarihi gündeme taşınmaktadır. Bu çerçevede, makalede kendilerini 16. yüzyıl son dönemi veya 17. yüzyıl başları erken dönemde Açe'ye geldiği varsayılan bir Türk yöneticinin soyundan geldiğini ileri süren Attahaşi ailesinin soykütüğü üzerinde durulmaktadır. Bu çalışmada, aynı zamanda söz konusu bu ailenin doğu Açe'de Sungai Iyu adlı yerleşim yeriyle tarihsel bağlantısı çerçevesinde, 19. yüzyıl ile 20. yüzyıl başlarında ekonomik-politik gelişmelere de kısmen değinilmektedir. Ailenin halen hayatta olan fertlerinin iddialarına göre, ailenin bazı üyeleri geçmişte Açe Darüsselam Sultanlığı'nın son yüzyılında Lam Kabeu ve Sungai Iyu'da yöneticilik yapmıştır. Bu çerçevede, bölgede bugüne kadar var olduğu ifade edilen Türk varlığının toplumsal ve siyasal izlerinin aydınlatılmasına katkı sağlayacağına inanılan ilgili veriler çeşitli yazılı belgeler, sözlü açıklamalar ile saha ziyaretleri ve gözlemlere dayanmaktadır. Söz konusu araştırma sırasında ve yazım sürecinde Banda Açe, Açe Besar, Sungai Iyu ve Medan'da başvurulan ilgili belgeler karşılaştırılmalı olarak değerlendirilmiştir. Yazılı belgelerdeki bilgiler ile aile ve ilgili kişilerle yapılan görüşmeler neticesinde elde edilen bilgilerin birbirleriyle örtüştüğü görülmektedir.

Anahtar Kelimeler: Attahaşi, gazi, Açe, Sungai Iyu, Lam Kabeu. 


\section{Introduction}

This is an illustration of Attahashi family ${ }^{1}$ who claims to be descendants of a Turkish "ruler" who came from "Anatolia" and resided in the late decades of the 16th century or at the beginning of the 17th century in Aceh Besar, Bandar Aceh. Throughout the centuries and across locations, the story of the family evolved through marriages and appointments closely bound to the Aceh Palace. This continued until the rule of the Netderlands Indies Government (NIG). Though the Sultanate of Aceh lost its independence, the Dutch colonial government kept on the administrative establishment and allowed an uleebalang, the traditional ruling class. Thus, the Attahashi family that had ruled Sungai Iyu ${ }^{2}$ for decades was re-officiated by the Dutch. The ancestor of the family is supposed to be a ghazi who was just one of the leaders within a group of people sent from Constantinople to Aceh in the 16th century.

I would like to delineate the Attahashi family and its connection to Sungai Iyu, particularly aligned with the eco-political developments in the 19th century and beginning of the 20th century. I took up this subject as a monographic research because it seemed quite authentic and it allowed to shed some light on the existence of Turks in Aceh. It is understood that the ruling members of the family exerted their influence quite significantly in Sungai Iyu and its surroundings, if the longer period of their rule is taken into consideration.

The data presented here has been collected through a vast number of visits to distinct venues (such as Medan, Sungai Iyu, Aceh Besar), interviews with family members and close circles of friends, and observations in the field since 2007. I first came across with the existence of the descendants of the above-mentioned ruler through a letter sent by some of the eldest members of the family, who then lived in Medan. I contacted an elder member of the family, Teuku Hamid, by telephone and visited the family thereafter. As soon as I had the opportunity at the beginning of 2008, I left for Medan. I found an address where a large number of people, sons and daughters, grandsons and other kin came together in a small house. They claimed to be descendants of a Turkish Ghazi, Al Ghazi Malik Manshur Kaisyeri Attahashi, an uleebalang first in Lam Kabeu ${ }^{3}$, Aceh Besar, and then in Sungai Iyu, Tamiang.

1 The name of Attahashi and relevant words and names quoted in the article are originated from a genealogical manuscript belonging to the the family.

2 Sungai Iyu, a sub-district on the east coast of Aceh, is under the administrative unit of Tamiang, where the grand fathers of the Attahashi family settled in the $19^{\text {th }}$ century and where the last generations still live. It is assumed that Sungai Iyu was ruled by one of the virtually independent local chiefs, as asserted by John Anderson, who were called uleebalang. See: Anderson (1971, p. 168).

3 Lam Kabeu is the name of the village still existing in the mountainous area of the Aceh Besar region, which is around 40 kilometers from Banda Aceh, capital city of the Aceh Province of the Republic of Indonesia. 
While these members were living in Medan, other members of the family still lived in Sungai Iyu. Though during the initial conversation, they did not mention anything about their connection to Lam Kabeu, I discovered through further research and visits to the area that some members of the kinship continued their simple lives in Lam Kabeu as well. Among the family members in Medan, two elder brothers and one elder sister were quite excited in the talk about their ancestors who were supposed to have come from thousands of miles away to this corner of the Archipelago. During the talks they showed some photographs of their father, the last uleebalang, and a Dutch document that proved that their father, as an uleebalang, was recognized and reappointed by the Dutch authorities during the pacification process in the latter years of the Dutch War in Aceh.

This article will talk about a concrete Turkish group in their own history. The discourse on Turks in the Aceh context has always been accorded to lada secupak ${ }^{4}$. Thus, Turks either were sent by the rulers in Constantinople or set off by their own initiatives somewhere around the Indian Ocean to search for their fortune and reached Aceh land in the Island of Sumatra. At least some of those people might have had salient histories that can be worth interpretation to some or larger extent.

With regard to this, this work can be considered a preliminary foray. To reconstruct the past of the above-mentioned family as far as possible, the author had enough valuable data documented by some individuals within the family itself. These documents describe, interestingly, a huge spacial relation between ancestors and descendants starting from a Turkic tribe in the Central Asia through Ottoman State and reaching to the Northern part of the Island of Sumatra. In this sort of research, social scientists are confounded by ill-balanced sources. In fact, when I first came across some portion of the family members and listened to their stories and collected the initial documentation, I inevitably felt the same restrictions. But what cleared the blurry picture are the various references, the existence of authentic settlements, and the larger group connected to the core family. All these aspects allowed me to trace the family's story. In case the written documents, say silsilahs, were too imaginative, then I would say that the individuals who scripted these materials were very creative and they are worth to be regarded as literature men. It is known that there is a dearth of information on eco-political deeds in Tamiang, 
eastern Aceh, and partly in the northern Sumatra region during the late decades of the 19th century. In this regard, I hope this work, beyond supplying information about one specific Turkic-origin family, supplies, though little, pictures of events within and around the region.

\section{Sources on the History of the Family}

Here, I should give some very brief information about where and how I acquired data on the Attahashi family. I have accessed four relevant documents on the background of the Attahashi family. The first is a larger silsilah covering almost all smaller and larger sultanates in Aceh history, which I collected as a photocopy from a retired colonel Arshad in 2005, who is also originally from Aceh Besar. The second is the letter that was sent by the family members living in Medan in 2007. The third is a silsilah that I received from the eldest member of the Attahashi family during my visit to Sungai Iyu, Tamiang, East Aceh. The fourth is a silsilah belonging to a family still residing in Lam Kabeu, Aceh Besar, who seems to be relatives of the Attahashi family although the nature of kinship is yet to be determined. In addition to these written documents, I collected valuable information through interviews conducted with relevant individuals, as mentioned above, in Medan, Sungai Iyu, Lam Kabeu, Desa Ajun Jeumpet, and Aceh Besar at various times. The fourth document, called 'Silsilah Nasab dan Zurriat Uleebalang Lam Kabeu dan Sungai Iyu', has been held by Teuku R. M. Oli bin Teuku Husin Lam Kabeu and his family to this day. It is understood that it is a reproduction that was rewritten in January 1975, in Medan. ${ }^{5}$

I should also emphasize that the field observations were sufficiently valuable to construct a complete story. These four written documents allow us to revive a ghazi originally from Rum and trace his connection to Aceh.

\footnotetext{
These documents seem to have been reproduced over the course of time. There are some understandable reasons for the reproduction process. For instance, the climate and the long term wars and conflicts can be assumed to be the reasons to have reproduced the original documents. As an example, the reminder collected from the fourth silsilah clarified this sort of situation. It is stated that this silsilah was rewritten by Teuku Syahbuddin Razi Pessenu who compiled and adapted various authentic sources such as Kitab Tempo Dulu, Patra (Terombo) Keturunan dan Lembaran Lepas (a manuscript called "Perbendaharaan Lama" which is regarded as "khazanah" for the Attahashi family). It is mentioned again that this rewritten silsilah was endorsed by Teuku Raja Johan and Ampon Raja Muluk Attahashi, who are the eldest members of the family. In addition, the first manuscript from the colonel is the largest one that is hung on the wall in his home. The second and third copies are rewritten samples by the eldest generation of the family, whom I came across in Medan and Sungai Iyu. Both are kept by the family in Sungai Iyu. The fourth copy from Lam Kabeu is in a rolled form and kept carefully in a bamboo protector.
} 
The above-mentioned fourth silsilah, belonged to a family in Lam Kabeu, Aceh Besar, who seem to be relatives of the Attahashi family with unclear ties of kinship to them. Teuku R. M. Ali bin Teuku Husin Lam Kabeue, the eldest member of the family, was above 80 and lost his ability to talk when I visited the family to collect significant data. The younger generation, nemaly his daughters, explained that they were unaware of the family's background. The first document is from a distantly related family's silsilah collected from former Colonel Arsyad in Desa Ajun Jeumpet, Darul Imarah, Aceh Besar at various times. ${ }^{6}$ A larger "printed" version of a silsilah acquired from former Colonel Arsyad includes some references to the Attahashi generation. The origins of this family are from Aceh Besar as well. Beside this valuable source, my observations and conversations with some individiuals also contribut to some extent during the visits in various times and places. In this regard, I should particularly mention Tengku Haji Adly Almaddany, a former civil servant at the office of Religious Affairs (Departemen Agama), Banda Aceh. The accounts of Almaddany sing that there were other families residing in the same region that also moved to the nothern coastal area as well. ${ }^{7}$

\section{Revival of A Historical Connection}

Exploring the Attahashi family history opens a new avenue of understanding of the Turkish presence in Aceh, which so far has been limited with to the story of Kampung Bitai and Emperoum. ${ }^{8}$ If the above-mentioned references (from the silsilahs, documents, and individual oral stories) prove the existence of other Turkish connections beyond the perpetual Bitai case. It may be assumed that the significance of the Attahashi family is quite real and more concrete if it is considered that the tsunami had already washed away the material facts and figures in Kampung Bitai and Emperoum. ${ }^{9}$

It may be worth asking here why this family resided in Lam Kabeu, in a mountanious area in Aceh Besar and what attracted them to move to this region. In this re-

6 I paid various visits to Colonel Arsyad who lives in the Ajun area, Darul Imarah, Aceh Besar in 2005 and 2015. He supplied supportive data beyond the Silsilah Raja Raja Islam di Aceh during the conversations, particularly about some families and their connection to Aceh Besar and other regions. This is a genealogy inherited by the family from generation to generation and the author met the holder of this material personally.

7 Tgk. Haji Almaddany, personal communication, August 2015, Kota Raja, Banda Aceh.

8 Teuku Ali Basyah Talsya, personal communication, October 2005, Leungbata, Banda Aceh.

9 Cut Keumala, personal communication, 12 November 2005, Emperoum, Aceh Besar; from the interview with Basyirun M. Nur, 12 November 2005, Bitai, Aceh Besar. 
gard, a few alternative views can be highlighted. It is generally known in the region that Aceh Besar has unique characteristics such as being surrounded by hills and mountains that house large plantation areas, forests, and no doubt an abundance of water resources in the form of rivers and underground springs. Even today, it can be witnessed that old wells in the early settlements are still filled with water. Some of these wells, which I personally observed during the field trip, are at least one hundred years old. In addition to these, the climate itself must have attracted Turkish elements since they had been accustomed to living in similar natural environments.

It is assumed that there were various Turkic groups who arrived at distinct times either by order of the Ottoman State or by their own initiatives. Regarding these groups, I explained this issue briefly by highlighting the name of ghazi when referring to some sources. I think it is quite rational to think that the newcomers chose to reside in familiar geographies that would also be paramount to pursuance of activities that they were accustomed to in their home countries, such as farming or animal husbandry. Aceh Besar, a rather large geographical area with a border zone to the territory of the central government under the direct control of the Sultan, was divided into three federated administrative units called sagi ${ }^{10}$ in the 16th century, or as some sources remark, the 17th century. The ruling elite of the sagis and the central government had rather complicated political and economic multilateral relations. We can assume that the mentioned Turkic groups were quite attracted by the rulers in sagi establishment. Since the former were qualified as prominent human power sent by the Khalifah, they might have been readily accepted. If their expertise in various sectors, such as military, architecture, trade, and even some religious scholarship, were taken into consideration, no doubt they would have found a place both among the Acehnese political elite and common folk. ${ }^{11}$

\section{Uleebalangship in Eastern Aceh}

The Sultans and the ruling elites took power in their hands particularly during the strong centralization periods and this power structure directed the expansion process and the appointments of local rulers in the newly conquered or recently

10 These sagis are called Mukim 22 Indrapuri, Mukim 25 Indrapatra and Mukim 26 Ladong. See: Hurgronje (1906, p. 82); Reid (1971, p. xii); Hing (1995, pp. 8, 15).

11 See below that in the genealogy of Sungai Iyu, there are some expressions such as "Pahlawan 7" and "Pahlawan 12" regarding the data in connection with the existence of the Turkish groups. (Note: It was observed and witnessed how the Acehnese accepted the Turkish people as their old friends religious "elder" brothers who came after the tsunami. It is probable that, in earlier centuries, the Acehnese behaved in the same or similar manner and attitude towards Turkish groups.) 
opened settlements particularly around the production centers. While the Sultans in Bandar Aceh ruled the whole country, they appointed governors, say, uleebalang (Ismail, 1991, p. 4 -f.n.11), for rural regions such as Tamiang in line with the expansion of the territories of the state as seen in the examples of the 16th and 17th centuries. The appointed governors were also responsible for the rural development of their respective regions. The governors got their political sovereignty via special decrees which were called as sarakata in Aceh history. ${ }^{12}$ Based on the current information and data, the governor of Tamiang who was appointed by a palace decree (sarakata) in the 19th century was a descendant of Ottoman-Turkish family.

As a common practice then, this area, which seems to have been given to a family close to the ruling elite, here Attahashi family, became an expansion of the Aceh Sultanate on its eastern border. In this regard, the growing global demand for pepper and the increase in its price forced the Sultanate of Aceh to do new plantations and, at the same time, keep the same areas under the strong control of both the British and the Dutch. During this period, the Sultan of Aceh agressively looked forward to new investments through his close circles including, as mentioned in the sources, "loyalist Acehnese Arabs, Penang based Indians and Acehnese merchants" (Nasution, 2014, p. 114). There were quite significant civil and military administrative bodies in Sungai Iyu including Kedatukan Mahkota Alam, Panglima Perang, Panglima Kaum Setia Raja and Datu Sri Bentara (Abdullah, 1994, p. 63). No doubt this administrative construction was a typical body observed throughout Aceh's history. Based on the characteristics of the members of the Attahashi family, such as civil and military capacity and capabilities, they were given the title of uleebalang and raja. Once an uleebalang was installed as the ruler of a far distant region, he was regarded as both an investor/enterepreneur and administrator. In addition, he played the role of war leader in the event of any wars or battles (Reid, 1979, p. 13). The appointees, who functioned as legal local rulers in the task of governors, held their legal sovereigny in the sarakata, an approved letter by the Sultan who still possessed sufficient power to do so. As with other locations, Sungai Iyu, Tamiang was also ruled by the Attahashi family who had a sarakata (Gade, 1991, p. xi).

12 The sarakata, the patent letters give us an idea of the way in which the sultan conceived of the office of the uleebalang. These documents have a seal at the top with the name of the sultan in the center and the names of eight sultans who ruled earlier periods are also present. See: Rouffaer (1980); Siegel (1969, p. 41). Regarding East Aceh, there were earlier appointments that gradually led regional development on the basis of demand for agricultural products. Accordingly, it should be mentioned Datok Po Kalam from Aceh Besar was appointed to rule Peureulak in the middle of the $18^{\text {th }}$ century. In addition, Sutan Muda, which is border area to Sungai Iyu was founded at the end of $18^{\text {th }}$ century and the Sultan of Aceh decreed a sarakata for an uleebalang to settle and rule Kejuruan Karang in 1808 (28 Sya'ban 1224). See: Ismail (1991). Ibid., p. 1 (f.n. 2). 


\section{Silsilah as Authentication of the Family Background}

Although I have not witnessed an original sarakata proving the claim of the Attahashi family, I came across a hand-written document in Latin script during my visit to a family connected to the Attahashi family in Lam Kabeu, and I was told that there is a "sarakata". ${ }^{13}$ Though the memory of the family cannot be objected to, the material object they showed does not reflect it. The material document they possess is not a classical jawi sarakata. Instead, it is written in Latin script as a reproduction based on earlier authentic material. However, this writing was likely quoted from another document which might have been a real "sarakata" in 1929. The title of this document is Silsilah Nasab dan Zurriat. It includes all the relevant ancestors and descendants of Attahashi family from the early centuries. Here as well, Sungai Iyu and the family of Attahashi are mentioned by the title of Lam Kabeu and Sungai Yu Administrator. Another salient issue is the note just below the main title that proves the historical significance of this document and that it was copied from a Jawi text possesed by Teuku Raja Husin bin Abdullah bin Lam Kabeu on 12 June 1929 (H. 22 Zilhijjah 1349). Here the word "patre" was used instead of "silsilah".

There is another significant note mentioning the name "Teuku R. M. Ali bin Teuku Husin Lam Kabeu", to whom this document was written just below the main title of the document. Teuku was a common title used for nobility who were also known as local rulers with their close family members (Ismail, 1991, p. xi). The last name after the title indicates the place where the aforementioned person ruled. In regard to this brief explanation, the name in the document indicates that R. M. Ali bin Teuku Husin was the ruler or descendant of the ruler in Lam Kabeu.

An authentic reference is mentioned on the top left side of the document, next to the main title of "From Past to Today Attahashi Family". Here, it is clarified that this silsilah was written by Teuku Syahbuddin Raizi Pessenu referring to Kitab Tempo Dulu, Patra (Terombo-Keturunan dan Lembaran Lepas (Manuscrip/Perbendaharaan Lama). ${ }^{14}$ There is a note about "Gazi Melik Mansur Kaisyeri Attahashi", the first generation of the Attahashi family who came and resided in Aceh Besar. Once Gazi Melik settled himself and this group of people, he was appointed as uleebalang at Sagi XXII, Mukim 5, Lam Kabeu. In addition to this, it is also emphasized that he was also later appointed as the ruler for Sungai Iyu. It is quite explanatory that the

14 Name and date are written at the end of the document as follow: Collected and confirmed, Medan-January, 1975, Teuku Syahbuddin Razi Pessenu. 
contemporary family bases its existence on this historical fact in Aceh. ${ }^{15}$ It is worth asking when and why Gazi Melik landed on Aceh. Based on the information in the silsilah, he came with a group of soldiers to Aceh in 1616, after Iskandar Muda requested some assistance from the Sultan of Ahmed I (1603-1617), the ruler of the Ottoman State. ${ }^{16}$ The number of the people in the group was 137 , seven of which were Gazi with the remaining 130 individuals including some artisans in various fields. ${ }^{17}$ Many in the group seem to be common warriors with some expertise such as producing cannon, building forts etc. The seven Gazi were also known as Pahlawan in Aceh's historical context. In particular, while the artisans took part in the developmental phases of Aceh, especially in the infrastructural investments in the capital city, the individuals who had military qualifications contributed in the war attempts of the Sultanate of Aceh against the Portuguese in Malacca. Hence, this information reminds us that this Turkish group came in 1566/67, during the last years in the reign of Alaaddin Riayat Shah al-Qahhar (1538-1570). ${ }^{18}$

This silsilah also exposes the origins of the Attahashi family beyond the Ottoman borders. With regard to this, this historical information releases whether the writer has used the formal historical resources or just based this explanation to the oral history transmitted generation to generation. But we should remember that the significant resource was the one mentioned above, quoted in 1929. Because of its importance, I would like to quote the information in the silsilah about the far distant origin of the family.

15 It is originally written as follows (in Indonesian language) in the silsilah: "Inilah Nenek Moyang Keluarga Attahashi di Aceh beliaulah leluhur Uleebalang V Mukim Lam Kabeue Sagi XXII Mukim Aceh Besar. Juga cakal bakal Uleebalang Negeri Sungai Yu Aceh Timur." It means, "This is the geneaology of the Attahashi family in Aceh. The mentioned person was the uleebalang at Mukim V Lam Kabeue Sagi XXII Mukim, Aceh Besar. He was also the pioneer uleebalang at Sungai Iyu, East Aceh."

16 Thomas Stamford Raffles remarks that the Sultanate of Aceh Darussalam was the tributary state to the Ottomans. Hence it became exempted during the reign of Iskandar Muda. See: Raffles (1991, p. 384).

17 These people are also called the higher title of "rank of major", based on the original writing as follows: berpankat mayor kestas (ke atas!).

18 For the major reference to this historical connection See: Mühimme Defteri (1995, pp. 118-119); Schrieke (1955, p. 44); Razaulhak (1967). This point is highlighted in the silsilah and the visits of Turkish groups are mentioned in historical sequence as: "Ottoman State sent envoys and assistance three distinct times. The first group including 313 soldiers with 'lada secupak' during the Ali Riayat Shah al-Qahhar (1537-1570); the second group including 12 Pahlawan (Ghazi) and 242 soldiers came during the Sultan Alaaddin Mansur Shah bin Sultan Ahmed Perak (1580-1585); and the third one Alp Melik and his groups. As argued by some researchers, Bandar Aceh, the capital city of the Sultanate of Aceh, was a cosmopolitan city because of its geo-strategic and geo-economic position in the middle of the East-West seaways. As a reflection of this geographical and economic fact, Turks seem to have visited this area, as did other groups of nations, particularly Gujaratis as well as Arabs, Chinese, Persians, Peguans. See: Siegel (1969, p. 37). 
In the very middle of the top section, the title is "Amir Khia Alp Attahashi". Here the epithets such as "Emir" and "Khia Alp" are quite important. "Emir" means the ruler or administrator in its classical meaning. To support this, it is seen that there is a Malay word, say, "Raja" that is a very common title used in Malay historiography. It continues by explanations to these political concepts. With regard to this, "Khia" means "son"; "Alp" means "lion". No doubt, these titles are a sign of the power and strength attached to the person or group of people. "Alp" is a common title used for the rulers in the old Turkic states in the Central Asia and the word "Attahashi" is met by Diberbapak in the Malay language.

The first paragraph in the silsilah details Alp Attahashi's tribe, his origins, and his conversion to Islam. There are quite symbolic expressions such as "Negeri Makan" (now known as the city of "Kokan") from where Alp Attahashi came; Puak, which is a sub-group under "Kabı" a larger tribe, is the name of his tribe. It is understood that "Alp Attahashi" originally came from a region between the Sri Derya and the Amu Derya Rivers in Western Turkistan. A contemporary information relevant to the political situation is also added by the writer saying that "this geography is now under the rule of Russia". There is detailed information about Puak, which is a sub-tribe that emerged from a mixture of Mongol and Indo-German in Turkistan, adjacent to Uyghur (Tarım), Western part of China and the Urals in Khazakistan. This tribe converted to Islam in the first century after Hijri. Khila Alp Attahashi lived in around 1100 (Hijri 500).

Here, the name of "Kab1 Lembah" is quite salient because the other silsilah and oral information do not use this name pertaining to connection with the family. The name is still used for a village in Seulimeum, Aceh Besar. As mentioned elsewhere in the article, Lam Kabeu (Kab1) was the family home prior to its move to Sungai Iyu in the end of the 18th century. The trace of the historical link makes it clear that the name of Lam Kabeu, the ruling area of the first generation of the family who came from Ottoman land to Aceh, was taken from the very initial stage of the tribe from the Central Asia. On the other hand, the explanation guides us to follow the trace of the family from Central Asia to the Ottoman era. With regard to this, the family is connected to "Şehzade Mustafa" one of the sons of Sultan Sulaiman I, Law Giver.

This brief referral to origin was signed by two witnesses of the family as a confirmation. I can say that Shahbuddin, the person who wrote this text in 1971 is one of the brothers whom I visited personally and interviewed in Medan in 2007. I was informed that he passed away some years ago and was burried in Medan. 
As it is tracked in major settlements of the villages, towns and cities in and around Aceh region, Raja Tamiang also settled near a river which remains known as "Sungai Iyu" to this very day, although in the modern era, the name of Tamiang is used for a larger segment of the territory between Langsa and Medan areas. In the past, there is no doubt that the early settlement was near a river bank. That's why the Negeri Tamiang is also known as Sungai Iyu, referring to a river.

\section{From Lam Kabeu to Sungai Iyu}

I would like to briefly refer to some points here that I noticed during my personal visit to Sungai Iyu in 2015. The eldest member of the family was Teuku Ahmet Mevlana (Ahmad Maulana). Though he was 87 years old, he was quite energetic -even accompanying me on foot without any hesitation or difficulty.

There was a picture on the wall in Ahmad Mevlana's house that I saw some years ago in Medan. This was the origional copy of the Raja Tamiang with his administrative body in front of the "istana". The "raja" seems quite self-confident in his power and his administrative staff, including Datuk Empat Suku, Datuk Lapan Suku etc. in the picture. After the latest "raja" passed away, based on his statements, the building was transformed into a masjid named "Baiturrasyidin Attahashi" located in the area called as Suka Mulia Village (Desa Suka Mulia). The family graveyard can be seen on the left side of the masjid as well.

The connection between Sungai Iyu and Lam Kabeu, Aceh Besar is based on the appointments of the Attahashi Pasha, as the head of both regions, and his descendants. He is mentioned as a descendant of a ghazi (Kesatria) named Malik Mansyur Kaisyeri who was contemporary to the era of Sultan Ahmed I in the Ottoman State, in $1652 .{ }^{19}$ Though there are some disconnects in the dates written in the silsilah, it follows the statements in Bustan'us Salatin, Sultan Ahmed I of the Ottoman State during his connection with Aceh in the ruling period of Iskandar Muda, who sent a delegation to Aceh. The Attahashi family argues that their grandfather was among that delegation. The Ottoman group was composed of 137 military experts and soldiers including Al-Ghazi, known as Pahlawan Tujuh, who participated in the war

19 The year and the name of the Sultan in Ottoman State is anachronic. If we consider the connection between the Ghazi and Sultan Ahmad I to be true, then the year should be between 1602-1612. (See: Teuku R. M. Ali bin Teuku Husin. (n. d). Silsilah Nasab dan Zurriat Uleebalang Lam Kabeu dan Sungai Iyu. This is a genealogy inherited by the family from generation to generation. The author met the holder of this material personally.) 
against the Portuguese. Al-Ghazi Al Amir Kaisyeri Pasya was later married to Pocut (Putroe) Meuh Laila Keusuma (Keumala) binti Teuku Raja Munawar Syah, one of the palace ladies, by arrangement of the Sultan Iskandar Muda. Al-Ghazi was also appointed as uleebalang of Mukim V, Lam Kabueu, Aceh Besar (Sekelumit Sejarah Negeri Sungai Iyu, p. 2). ${ }^{20}$

Regarding the data already disseminated from generation to generation about their ancestor, the Attahashi family believe themselves to be descendants of an Ottoman-Turk who claimed to be one of the members sent by the Ottoman State in around 1566-67. It is understood that the newcomers settled in Krueng Raya, Aceh Besar, over the course of time. But the turning point for the family is the time of the late decades of the 18th century. Hence, in this point, we are not sure whether the early generations of the family resided originally in Krueng Raya or not, or what position they held in Krueng Raya. On the other hand, it should be considered that there could have been a connection and communication through the road in the mountainous area between Kampung Lam Kabeu and Krueng Raya. ${ }^{21}$

I would like to focus on the individual rulers in Sungai Iyu. There are four significant rulers that successively led the region based on this silsilah. The rulers of Sungai Iyu are as follow accordingly:

20 This is a genealogy inherited by the family from generation to generation. The author met the holder of this material personally. (Note: Al-Ghazi had three sons from this marriage and all were appointed as rulers in regions as follows: Teuku Panglima Polem Muda Cut Sakti Lam Cut, Panglima Sago XII, Meukim Aceh Besar; Teuku Maha Raja Polem, ulee baling V, Meukim Lam Kabeu; Teuku Raja Abdullah, uleebalang V; Meukim Lam Kabeu. See: Ibid. I would like to say that there seems to have been some distinct settlements in Lam Kabeu based on the names given above.) For Melik Mansyur See: Silsilah Raja Raja Islam di Aceh, possessed by retired colonel Ershad, Banda Aceh. (Note: The full name of the first generation who is supposed to have come to Aceh in the mid of $17^{\text {th }}$ century is as follow: Elmir Kaiseri Attahashi Pasha, Pahlawan Maharaja Sri Setia. See: Bantasyah (2007, pp. 2-3). On the other hand, the date and the name of the Ottoman Sultan are not correct, and it seems there is anachrony in this information since, in the mentioned year, Aceh was ruled by the first Queen, Safiatuddin. During this period there was no war fought against the Portuguese. Instead, it is known as peaceful era. Notwithstanding, it is mentioned that Attahashi came to Aceh in the $16^{\text {th }}$ century. (See: Sekelumit Sejarah Negeri Sungai $I y u$, p. 1.) If all three manuscripts are compared, a conclusion can be reached that the century must be $16^{\text {th }}$, not $17^{\text {th }}$. There is also an error in the text. (Note: I should refer here to another silsilah from Lam Kabeue about the origin of Gazi Melik. His complete name, one of the seventh Pahlawan (Ghazi), is as follows: Gazi Melik Mansur Kaizeri Attahashi bin Emir Süleyman bin Emir Mansur bin Şehzade (Kroom prins) Mustafa bin Sultan/Khalifah Sulaiman I, Law Giver, and he was the Governor of the province of Kaiseri (Kayseri). And he should have been married to the daughter of the Raja Munawwar Shah Raja Muda, the Governor of Pariaman who was the brother of Sultan Iskandar Muda. Hence it does not coincide with historical fact about Şehzade Mustafa. He did not get any position in Kayseri but in Saruhan -Manisa, Amasya and Konya as Sancakbeyi.)

21 Muhajir al-Fairus, personal communication, August 5, 2015, Lamgugob, Banda Aceh. (Note: He is a lecturer at UIN Ar-Raniry and a distant relative of the family of Dayah Tanoh Abee. 
1.Raja Lubok or Teuku Setia Maharaja (1831-1894).

2.Raja Johan Alamsyah or Teuku Ch'ik Muda Panglima (1843-1872).

3.Raja Athas or Teuku Muda Ch'ik (1894-1909).

4.Raja Siddik or Tengku Ismail, Tengku Ampon Ch'ik Raja Ismail Siddik Attahashi (1909-1949) (Bantasyah, 2007, p. 4). ${ }^{22}$

Before going into detail about the rulers of Sungai Iyu in order, I should first explain how the family was involved in the Sungai Iyu, Tamiang region. Based on the data, the first contact with the Tamiang region was based on trade business and a sort of love business at the same time. With regard to this, Abdullah, the third son of Elmir Kaisyeri Attahashi, had trade business with Penang Island (Bantasyah, 2007, p. 3). Raja Abdullah ${ }^{23}$ asked for his mother to arrange his marriage with the sister of Raja Bendahara Tamiang. Convinced by this sons's request, the mother left for Tamiang with Uleebalang Lam Kabeu to arrange the marriage with Tengku Ratna Indra (Pocut Ratna Indra). After a while, Raja Abdullah married to the mentioned lady in 1752 (Sekelumit Sejarah Negeri Sungai Iyu, p. 3). ${ }^{24}$

Ratna Indra gave birth to a boy for Raja Abdullah in 1754, who was to be later called Teuku Raja Lubok (Sekelumit Sejarah Negeri Sungai Iyu, p. 4). Some time later, Raja Abdullah requested some areas from his brother-in-law to facilitate gardening in the area of Rimba, which he had come to know during his above-mentioned voyage. Upon agreement from his brother-in-law, Raja Abdullah returned to Aceh Besar to bring some villagers to Tamiang. The group of villagers headed by Tengku Tinggi were settled in the area known today as Seuneubok. Raja Abdullah named this place Telaga Meuku and established an area now known as Bandar Baru ( $S e-$ kelumit Sejarah Negeri Sungai Iyu, p. 4). He was entrusted by the Sultan of Aceh, as the ruler to collect tax and other revenues in Sungai Iyu (Bantasyah, 2007, p. 3). ${ }^{25}$

Note: Hence it is observed there are some differences in the silsisah Sekelumit Sejarah Negeri Sungai Iyu about the dates: 1. Raja Lubok or Teuku Setia Maharaja (1779-1831); 2. Raja Johan Alamsyah or Teuku Ch'ik Muda Panglima (1834-1869); 3. Raja Athas or Teuku Muda Ch'ik (1872-1909). See: Ibid., p. 1.

23 Raja Abdullah, Descendant of Turki, To The Negeri Bendahara Tamiang. Raja Abdullah, one of the sons of Elmir Kaisyeri Attahashi Pasha, was conducting business as a trader between Aceh and the Penang Island beyond his function as the local governor. Once upon a time, his sailing boat was skid away in the Malacca Straits and arrived somewhere around the region of Tamiang. He found clean water for the people in the boat. Later on, he continued his journey to the Penang Island and returned to Krueng Raya, Aceh Besar. (See: Sekelumit Sejarah Negeri Sungai Iyu, p. 3.) In addition, he seems to have been appointed as uleebalang V Mukim Lam Kabeu. See: Bantasyah (2007, p. 3).

24 Note: A son was born from the above-mentioned marrige in 1754 and named Teuku Raja Lubok. See: Sekelumit Sejarah Negeri Sungai Iyu, p. 4.

25 But the name of Raja Abdullah cannot be traced as the uleebalang of Sungai Iyu in a further reference. Instead the other names are mentioned as emphasized above. See: Sekelumit Sejarah Negeri Sungai Iyu. 
Based on the family tree, the generations of the family settled and ruled as governors of Sungai Iyu between the years of 1830-1949 (Bantasyah, 2007).

Teuku Setia Maharaja (Teuku Ch'ik Raja Lubok) (1779-1831) (Sekelumit Sejarah Negeri Sungai Iyu, p. 6; Teuku R. M. Ali bin Teuku Husin. (n. d). Silsilah Nasab dan Zurriat Uleebalang Lam Kabeu dan Sungai Iyu): ${ }^{26}$

Though there is no significant data about the early stages of the family, it is understood that Teuku Setia Maharaja (Attahashi), also called Raja Lubok (17911831), was appointed as the first ruler (uleebalang) of Sungai Iyu, Aceh Timur in 1831 by the then Sultan of Aceh (Sekelumit Sejarah Negeri Sungai Iyu, p. 1; Bantasyah, 2007, p. 4) ${ }^{27}$ Thus, he should be considered the founding ruler of Sungai Iyu. The title used for Teuku Cik Raja Lubok was "Teuku Seutia Maha Raja”. His father was Teuku Maha Raja Muda Abdullah, the last uleebalang Mukim V, Lam Kaeu. ${ }^{28}$ Raja Abdullah, as mentioned elsewhere, was also relative of the Kedah Palace via his marriage, and was uleebalang Cut Sungai Iyu Bendahara Tamiang. His mother was Pocut Ratna Indra, sister of uleebalang Raja Bendahara. He had two children, a girl and a boy, named Pocut Kemala, and Teuku Muda Panglima Johan Alam Syah (Sekelumit Sejarah Negeri Sungai Iyu, p. 6) ${ }^{29}$ This marriage is quite a good example

26 Personal visit to the family, 2 August, 2015. (This is a genealogy inherited by the family from generation to generation and the author met the holder of this material personally.) (Note: There is a slight different in the year of death, 1869. See: Ibid. It is probable that it was wrtiten this way because of a spelling mistake.)

27 Note: There is a difference about the date of Raja Lubok. In the first reference mentions (1779-1831), and the second one mentions (1831-1894). See: Ibid.

28 The full name was written as follows in another document prepared by the family members in Medan: "Raja Lubok, Teuku Setia Maharaja (1831-1894), the founder of Kejuruan Sungei Iyu, Negeri Tamiang, in Eastern Part of Acheh. See: Bantasyah (2007, pp. 2, 3). (Note: There is complete information about Raja Muda Abdullah in the silsilah possessed by the family in Lam Kabeue which I personally paid a visit and had a conversation with. During the visit, the family shared the silsilah with me. Raja Muda Abdullah is described as the latest uleebalang of Lam Kabeu Mukim V. He was appointed as the uleebalang Sungai Iyu by Sultan Alaaddin Muhammad Daud Syah (1824-1838). He was charged as the head of all the local rulers in the Sungai Iyu area on behalf of the Sultan. He was the controller of the trade business between Sungai Iyu, Penang, and Singapore Islands. According to the data, he also took part in the war between the Sultanate of Kedah and Siam Kingdom. See: Teuku R. M. Ali bin Teuku Husin. (n. d). Silsilah Nasab dan Zurriat Uleebalang Lam Kabeu dan Sungai Iyu.

29 Note: Pocut Keumala was also titled as Tengku Kemala. Her husband was Teuku Raja Akup, Uleebalang Pase. Their son, named Teuku Raja Hitam, was born from this marriage. See: Sekelumit Sejarah Negeri Sungai Iyu, p. 7; Silsilah Nasab dan Zurriat. (Note: Teuku Muda Panglima Johan Alam Syah, whose title was Teuku Chi'k Muda Panglima Johan Alam Syah, was the son of Teuku Raja Lubok (Teuku Seutia Maha Raja), the first ruler of Sungai Iyu after he was appointed by Tuanku Alaaddin Ali Iskandar Sulaiman Syah, the Sultan of Aceh. His wife was Cut Tanglong (Cut Aluw) binti Teuku Chi'k Meulila, Keujureun Chi'k Uleebalang Langsa. He had one daughter whose name was Cut Manya'k. See: Sekelumit Sejarah Negeri Sungai Iyu, p. 7. (Note: There is a neighboring area in Sungai Iyu which is called "Manyak". Personal observation.) 
of the intra-regional connections in the Archipelago. These arranged marriages had served the purpose of cultural and economic connectivity among the various ruling elites of petty states in the region (Chou, 2005, p. 243).

Teuku Cik Raja Lubok was known as the founder of Sungai Iyu between 17791834. During this time, the region became populated by migrants, particularly from Bandar Aceh, and developed in terms of agriculture (Sekelumit Sejarah Negeri Sungai Iyu, p. 6). ${ }^{30}$ This coincided with the gradual increase in demand for pepper, particularly by the European powers in the region, especially at Penang Island. So the establishment of Sungai Iyu seems to have been a quite strategic investment undertaken by the Sultanate circles in Bandar Aceh. On the other hand, there was more than one establishment in Tamiang region during this era. With regard to this, Bendahara Tamiang, another establishment in the document, was ruled by Tuanku Hasyim Banda Muda. It is argued that Raja Lubok contributed more as he became more successful in ruling his area than Tuanku Hasyim Banta Muda ( $S e$ kelumit Sejarah Negeri Sungai Iyu, p. 6). ${ }^{31}$

Here it should be emphasized that the role of uleebalang was still very relevant in collaboration with the Aceh Palace. Uleebalangs seem to have functioned in enterpreneurship in the field of agriculture to the advantage of the Aceh sultanate throughout the centuries, though there were constant power struggles in central politics. In this context, uleebalangs were regarded as "pioneers and financiers of the opening of new pepper-growing plantations. If the candidate also had political and military skills, he would become the raja or uleebalang of a little statelet, but continued to derive his income almost exclusively from trade business. By controlling a port or river, he levied a five percent toll on all imports and exports; pepper and betel exports, as the major crops, which earned him a special return of about a dollar a picul and much of the produce of his statelet was controlled entirely by him as the principal capitalist and trader" (Reid, 1979, p. 13).

After some years, Chik Raja Lubok requested Sultan Alaaddin Ali Iskandar Sulaiman Syah (1830-1835), the Sultan of Aceh, to appoint his son Teuku Muda Panglima Johan Alam Syah into his place in 1834. This request was accepted by the palace and Teuku Muda Panglima Johan Alam Shah was appointed as raja with the right of sarakata and cap sembilan, which means he had full uleebalangship position in 1831 (Sekelumit Sejarah Negeri Sungai Iyu, p. 6).

\footnotetext{
30 Note: Here it seems a contradiction between the dates given in the same source. The first data given for his ruling years between 1779-1834, and the second one is 1779-1830. See: Ibid.

31 Note: A proof about Tuanku Hashim's rule over the region was observed and witnessed by John Anderson during his visit to the region in 1823. See: Reid (1969, p. 45).
} 
Teuku Ch'ik Muda Panglima Raja Johan Alamsyah (1834-1869):

Teuku Ch'ik Muda was appointed ruler with full authority of uleebalangship as mentioned above. Because of this status of rulership, he might be regarded as the first ruler of Sungai Iyu with a sarakata with cap sembilan from the Sultan of Aceh (Sekelumit Sejarah Negeri Sungai Iyu, p. 1; Bantasyah, 2007, p. 4). ${ }^{32}$ His father was Teuku Raja Lubok (Teuku Seutia Maha Raja), the founder of the Negeri Sungai Iyu (1831), the representative of the Palace of Aceh during the era of Sultan Alaaddin Ali Iskandar Sulaiman Syah (1830-1835). His mother was Cut Tanglong (Cut Aluw) binti Teuku Chi'k Meulila, Keujureun Ch'ik Uleebalang Langsa and he had a daughter whose name was Cut Manya'k. (Sekelumit Sejarah Negeri Sungai Iyu, p. 7).

Teuku Muda Panglima Johan Alam ruled the region as Bendaraha Tamiang between 1834 and 1868. During his era, the territory of Sungai Iyu was expanded in the east and west with new initiatives of opening new agricultural fields and employing migrants in the plantations. He also collaborated with some other neighbouring ruling elites. This era witnessed increasing trade relations between North and East Aceh and Penang Island. Teuku Muda involved himself in this trade business in accordance with his family's tradition. Concurrently, family ties to Kedah Palace in the Malay Peninsula gave greater accessibility to the business circles from the Sungai Iyu (Sekelumit Sejarah Negeri Sungai Iyu, p. 8) ${ }^{33}$ Teuku Muda passed away in 1868. Since there was no legal inheritance to become new ruler, his father Raja Lubok, though too old, acquired responsibility for a very short period of time. Teuku Ch'ik Raja Athas was appointed the new ruler of Sungai Iyu in 1872 (Sekelumit Sejarah Negeri Sungai Iyu, p. 8). After he passed away, the elite group suggested his father, Teuku Raja Lubok, would be replaced. Since he was too old, he could not be reappointed to rule the region again. Instead, Teuku Chik Raja Athas, the nephew of Teuku Muda was appointed as the new ruler from 1872. Raja Athas was the son of Teuku Raja Husin Banta, deputy of Raja Lubuk (Sekelumit Sejarah Negeri Sungai Iyu, p. 8).

The close relations between Aceh and Penang Island during this time are worth mentioning. Though the capital city of the Sultanate of Aceh had quite close relations with Penang, the East coast of Aceh gradually improved its trade business with the Island. During the early decades of the 19th century, among the population of the Island, there was an Acehnese community who became permanent

32 Note: Cap which was widely used in Malay sultanates proved that the owner had political power to some or larger extent. See: Ab. Karim (2006, p. 327).

33 Note: The years are slightly different at Silsilah Lam Kabeu as 1831-1867. See: Teuku R. M. Ali bin Teuku Husin. (n. d). Silsilah Nasab dan Zurriat Uleebalang Lam Kabeu dan Sungai Iyu. 
settlers (Newbold, 1971, pp. 54-55). ${ }^{34}$ Hence, there is still little detail on the identification of traders and the exact nature of their activities in Sungai Iyu and Eastern part of Aceh. It is also worth asking whether the traders from the other side of the Straits of Malacca, originally the British or Chinese merchants or the Acehnese themselves including the Raja himself, were exclusively involved in trade business.

During this time, Tamiang felt the political influence and pressure of Dutch colonial rule, which already had some agreements with a few rulers in North Sumatran petty states. With regard to this, it can be asserted that the capital city of Banda Aceh, Tamiang, as a part of the Sultanate of Aceh, had prior witnessed the forcing policies of the Dutch, even though territorial sovereignty of Aceh was guaranteed in the 1824 London Treaty (Chaniago, 2002, p. 27; Reid, 1969, p. 46). On the other hand, in the earlier decades the Sultanate of Aceh had sovereignty over the Northern Sumatran petty states and, during the course of time, the Dutch conducted aggressions into the region and colonial imposition was strongly felt in North Sumatran petty sultanates. Thus, through either mutual relations or benefits, as seen in the form of economic and political power, the native rulers such as Siak Sultan were attracted and the Dutch made them sign an agreement. The Dutch intended to expand their territorial hegemony into the area of Tamiang, which was known as economically valuable agricultural fields, pertaining to the Siak Treaty of 1858 (Tarling, 1969, p, 161; Reid, 1969, p. 46). This caused a sort of dispute between the British and the Ducth authorities. "The Dutch controleur in Deli was deputed to settle the affair. He quickly retreated from Tamiang, empty-handed and fearful, after having his moustache pulled by the irreverent Atjehnese. The Raja Bandahara claimed to be a subject of the Sultan of Atjeh, and remarked the official bluntly that "if English subjects were molested by his men, he did not require the mediation of the Dutch government." (Reid, 1969, p. 46).

Tengku Muda Ch'ik (Raja Athas, 1872-1909):

The third ruler of Sungai Iyu as uleebalang was Tengku Cik Raja Athas, also titled as Teuku Muda Chik, who governed Sungai Iyu from 1872. After the Dutch invasion and their rule in the eastern Aceh, based on the agreement between the local rulers and the Ducth authorities, Raja Athas was appointed as Zelfbestuurder van Soengei Ijoe (autonomous rulers of Sungai Iyu) by the Dutch authorities (Sekelumit Sejarah

34 The Acehnese community in Penang Island were as follows: "The population in 1801, amounted to 10310, in 1805 to 14.000 , in 1822 including Province Wellesley to 51,207; in 1826 to 55,116, in 1828 to 60,551 , and in 1833 to 86.275 . The following census (for 1833) will give an idea of the mixed nature of the population of Pinang." (Ibid.) 
Negeri Sungai Iyu, p. 1; Bantasyah, 2007, p. 4). This was a position inevitably given by the Dutch since the administration of Aceh historically had been carried out by the system of local rulership, the uleebalang. It is also understood that there were minor uleebalangs and religious scholars who worked in collaboration with the uleebalang in the system of local government. As argued in some sources, Sungai Iyu was among the "103 self-governing statelets" (Reid, 1979, p. 12).

Though we could not learn anything from the document about his relations with the Palace of the Sultanate of Aceh, this appointment allowed him to continue his governance accordingly. The grave of Raja Athas is in Bandar Baru village, Sungai Iyu, just few kilometers from the old palace (Sekelumit Sejarah Negeri Sungai Iyu, p. 1; Bantasyah, 2007, p. 4).

He was the son of Teuku Cik Raja Husin (Teuku Maha Raja Husin Banta), the son of Teuku Maha Raja Muda Abdullah, the last uleebalang of V Mukim Lam Kabeu. ${ }^{35}$ His mother was Pocut Merah Puteh binti Teuku Maha Raja Badauddin, uleebalang Krueng Raya, Aceh Besar. In addition, as seen in the abovementioned brief context of family, he was the younger brother of Teuku Seutia Maha Raja (Teuku Raja Lubok) (Sekelumit Sejarah Negeri Sungai Iyu, p. 9).

He married three times. According to the silsilah, his first wife was Wan Zuriah Bin Teuku Panglima Sungai Pantai Kedah, mother to his three children:1.Tengku Banta Ahmad Attashi; 2.Cut Ijo Attashi; 3.Teuku Ismail Attashi. From his second wife, Chek Medan Haji Aisyah from Medan, he had one child whose name was Teuku Salamah Attashi. She later married Teuku Abdullah, the son of Raja Kuala Simpang. Teuku Raja Athas's third wife was Teuku Siti, daughter of Raja Kuala Simpang. From his third wife, he had a daughter, named Pocut Marchan Attashi. Pocut Marchan was married to the son of uleebalang Meuredu (Sekelumit Sejarah Negeri Sungai Iyu, p. 10).

Raja Athas actively initiated the construction, particularly in the first three years, in order to develop the region. First he brought new migrants as labour power, since the local population was not enough, from Banda Aceh to settle in and around Sungai Iyu such as in the border area of Rimba. This human power was neither functionalized in the plantation, nor in the modernization process. With regard to this, the new settlers cleaned the area to open a new road $^{36}$ and to build a 
palace complex, a school with a teacher lodge, a small mosque, a bridge to connect both sides of the Sungai Iyu, and a market place (saran pembangun dari Sungari alur kemiri sampai alur cantik dan ke Tungku Tinggi.) It is understood from the document that the school has functioned as a sort of Qur'an school, since the two-story building served as both a school and a masjid. This modernisation process was completed in 1875. One can conclude that the major improvement in the region was realised during the rule of Teuku Cik Raja Athas (Sekelumit Sejarah Negeri Sungai Iyu, p. 10). In addition, a new housing project was also carried out for new comers. While the population and modernization were mutually aligned, the trade between Sungai Iyu and other establishments around the region also improved (Sekelumit Sejarah Negeri Sungai Iyu, p. 11).

Raja Athas also directed the building of an Istana called "Kandaria" in Desa Tanjung Sungai Iyu. This building functioned as administration office as well (Sekelumit Sejarah Negeri Sungai Iyu, p. 11). ${ }^{37}$ This building can be considered a landmark in the region that was converted to Masjid Baiturrasyidin and is currently in service.

\section{Teuku Ismail Siddik (1909-1945):}

Teuku Ismail Sidik, known as Teuku Raja Ismail Sidik Attahashi, was the fourth and last ruler of Sungai Iyu, Bendahara Tamiang in the years between 1909 and $1945 .^{38}$ He signed an agreement letter (Kerte Verklaring) written by the Dutch Indian Colonial Government on 25th June 1909, and was appointed the autonomous ruler, like his father, in the region on the authority letter of A. F. Van Idenburg, the then Governor of Dutch Colonial Government, Batavia (Jakarta) on 3 October 1910 (Sekelumit Sejarah Negeri Sungai Iyu, p. 15). Sungai Iyu was under Tamiang Onderafdeeling, Kuala Simpang, the administrative capital area of East Aceh. During that time the Dutch called the area as 'Zelfbestuurder van Soengei Ijoe (Sekelumit Sejarah Negeri Sungai Iyu, p. 1). Ismail Siddik continued his rule during the Japanese invasion for almost two and half years (Sekelumit Sejarah Negeri Sungai Iyu, p. 15).

His father, Teuku Raja Athas (Teuku Muda Chi'k), was the first autonomous ruler under the Dutch colonial regime and his mother was Wan Zuriah bin Tengku

mentioned in Acehnese version of Undang Undang Melaka “... He who establishes a village outside must also open a road." See: Fang (1976, p. 10).

37 Note: The author personally paid a visit to Sungai Iyu and was shown this building by the son of Ismail Siddik, the last ruler. Ahmad Maulana, personal communication, July 22, 2015, Sungai Iyu.

38 He was appointed as Kejuruan by the title of Teuku Ampon Chik Raja Ismail Siddik Attahashi, 19101942. See: Sekelumit Sejarah Negeri Sungai Iyu, p. 15. 
Panglima Sungai Petani, Kedah. His first wife was Siti Aminah Nasution (Cut Raye'uk) who gave birth to a daughter, Cut Putri Khadijah (Tengku Puteri). From the second marriage with Cut Mahawi (Cut Po) he had six children named Teuku Raja Muluk Attahashi (Ampon Muluk), Teuku Raja Mahmud (Ampom Mahmud) (Sekelumit Sejarah Negeri Sungai Iyu, p. 14), Cut Sari Banun (Tengku Banun Attahashi), Cut Mariam (Tengku Mariam), Teuku Raja Ali (Tengku Ali), Teuku Idrus (Tengku Idrus); from his third wife Enc'ik Habiba (Enchi'k Bah) he had Cut Fatimah Syam (Tengku Fatimah), Teuku Raja Sulaiman (Tengku Leman), Teuku Raja Johar Nur (Tengku Johar), Cut Bunia Ratun (Tengku Bunia), Cut Nilam Cahaya (Tengku Nilam); and from the fourth wife, Cut Nya'k Han (Cut Han), he had a single daughter, Cut Sri Damaliah (Tengku Suri) (Sekelumit Sejarah Negeri Sungai Iyu, p. 15).

While he was the ruler both under the Dutch and Japanese colonial regimes, he ran his sub-district accordingly; investing in the developmental processes. In particular, during the sovereingty of the Dutch, economic advancement kept pace with the rest of Eastern Sumatra with roads connecting various plantation villages and markets. Also in line with general Dutch policies, a new labour force of migrants, particularly from Java Island, were brought to the newly opened plantations. This era also witnessed the rise of some individuals among the newcomers to community leadership, having been appointed as local rulers such as village heads (keuchik) (Sekelumit Sejarah Negeri Sungai Iyu, pp. 13, 15).

The ruling period of Teuku Raja Ismail Siddik Attahasi continued during the Japanese invasion between 1942 and 1945. The transition period witnessed the local rulers' political determination in Aceh between Aceh's independence and the establishment of the Republic of Indonesia. Teuku Raja Ismail seems to have been recognized by Daud Beureueh, the leader of Aceh after the Japanese left the country. Furthermore, after the Aceh region united with the central government of Jakarta in 1949, the long ruling period of Teuku Raja Ismail ended. He passed away on February 4, 1949 and was buried in the garden of the palace complex. Teuku Raja Ismail bequested the palace complex in Tanjung Sungai Iyu to be converted into a masjid and the field next to it would become a family graveyard (Sekelumit Sejarah Negeri Sungai Iyu, p. 16). In regard to this, it is assumed that Teuku Raja Ísmail successively adapted himself to the changing political atmosphere during his long-term rule. It was general tendency among the local elite to surrender to the Dutch rule, after the initial stage of the Dutch War and particularly in the context of East Aceh, the military struggle in 1880 did not succeed againt the Dutch.

The era of Teuku Ismail Siddik ended with the Japanese invasion. Based on the information from Teuku Maulana, one of his sons, he bequested the adminis- 
tration headquarters, bulit in 1872, to be converted into a masjid. With the help of the local people, this will was realized and it has been in service to the present day. It is a two-storey building with a large complex, including a long entry passage connecting to the road, a kitchen, and a security office on the grounds around it. ${ }^{39}$

\section{Conclusion}

It should be emphasized that this article is assumed to make some contribution to the historical existence of the Turks in Aceh by taking into consideration a family who claim to be descendants of a Turkish ruler, a ghazi, originally from Anatolia. The illustration of the Attahashi family is based on various silsilahs that are also supported by oral stories from individuals in relevant regions in Aceh. Though the story of the family commenced in the relatively early era of the Sultanate of Aceh Darussalam, some members of the latest generations of the family who were appointed as uleebalangs, known as regional administrators or local rulers, in Sungai Iyu, are traced accordingly in the above-mentioned sources. Although these later dated silsilahs seem to have some shortcomings and defects, they certainly provide very valuable data on the traces of the Turkish existence in Aceh. These rulers, from the early 19th century onwards, were recognized not only by the central rulers of the Sultanate but also during the Dutch colonial rulers in the beginning of the 20th century. The output of this research is to revive a constant rulership of a family, from an early generation to latest one, from the Sultanate of Aceh Darussalam until the end of the Japanese invasion.

\section{References}

Ab. Karim, Ab. Razak. (2006). Surat Sultan Ahmad Tajuddin Halim Syah: Stilistik Penulisan Warkah Melayu Lama. In Rogayah A. Hamid; Mariyam Salim (Eds.), Kesultanan Melayu Kedah (pp. 323-356). Kuala Lumpur: Dewan Bahasa dan Pustaka.

Abdullah, A. (1994). Kebudayaan Suku-Suku Bangsa Di Daerah Aceh, Lembaga Pengabdian Kepada Masyarakat. Darussalam: Universitas Syiah Kuala.

Anderson, J. (1971). Acheen -and the Ports on the North and East Casts of Sumatra-, with an Introduction by A. J. S. Reid. Kuala Lumpur: Oxford University Press.

Bantasyah. (2007, May). The Turkey Descendents in Kejuruan Sungei Iyu, Negeri Tamiang in Eastern Part of Acheh (18301949), Medan.

Chaniago, J. R. (2002). Perlawanan Tokoh Tokoh Masyarakat Aceh Terhadap Rezim Kolonial Belanda, Arsip Nasional Republik Indonesia. Jakarta: Proyek Pemasyaratakan dan Desiminasi Kearsipan Nasional (ANRI-Arsip Nasional Republik Indonesia). 


\section{The Journal of Humanity and Society}

Chou, C. (2005). Southeast Asia Through an Inverted Telescope: Maritime Perspective on a Borderless Region. In Paul H. Kratoska; Remco Raben; Henk Schulte Nordholt (Eds.), Locating Southeast Asia. Geographies of Knowledge and Politics of Space (pp. 234-250). Singapore: National University of Singapore.

Fang, L. Y. (1976). Undang-Undang Melaka (The Law of Melaka). The Hague: Martinus Nijhoff.

Hing, L. K (1995). The Sultanate Of Aceh-Relation with the British 1760-1824, South East Asian Historical Monograph, Kuala Lumpur: Oxford University Press.

Hurgronje, S. (1906). The Acehnese, (A. W. S. O’Sullivan, Trans.), II, Leiden: E. J. Brill.

Ismail, M. G. (1991). Seuneubok Lada, Uleebalang, Dan Kumpeni Perkembangan Sosial Ekonomi Di Daerah Batas Aceh Timur, 1840-1942, Leiden.

Langenberg, M. van. (1977). North Sumatra Under Dutch Colonial Rule: Aspects of Structural Change. Review of Indonesian and Malayan Affairs, 11. (pp. 74-111).

Mühimme Defteri. (1995). 7 Numaralı, (975/1567-1569), Özet-Transkripsiyon ve İndeks I, T. C. Başbakanlık Devlet Arşivleri Genel Müdürlüğü, Osmanlı Arşivi Daire Başkanlığı Yayın No: 28, Ankara.

(n. n). (n. d.). Sekelumit Sejarah Negeri Sungai Iyu, [held by the family in Medan].

(n. n). (n. d). Silsilah Raja Raja Islam di Aceh, [held by Colonel Arsyad, in Ajun, Aceh Besar].

Nasution, K. S. (2014). The Chulia in Penang: Patronage and Place-Making Around the Kapitan Kling Mosque 1786-1957, Penang: Areca Books.

Newbold, T. J., (1971). Political and Statistical Account of the British Settlements in The Straits of Malacca, Volume I. Kuala Lumpur: Oxford University Press.

Raffles, S. (1991). Memoir of the Life and Public Services of Sir Thomas Stamford Raffles. Singapore: Oxford University Press.

Razaulhak Şah. (1967). Açi Padişahı Sultan Alaaddin'in Kanuni Sultan Süleyman'a Mektubu. Ankara Üniversitesi Dil ve Tarih Coğrafya Fakültesi Tarih Araştırmaları Dergisi, V, 8-9, (pp. 381-388).

Reid, A. (1979). The Blood of the People: Revolution and the End of Traditional Rule in Northern Sumatra. Kuala Lumpur: Oxford University Press.

Reid, A. J. S. (1971). "Introduction", Acheen -and the Ports on the North and East Coasts of Sumatra-. (pp. v-xvi). John Anderson, Kuala Lumpur: Oxford University Press.

Reid, A. (1969). The Contest for North Sumatra: Atjeh, The Netherlands and Britain 1858-1898. Kuala Lumpur: University of Malaya Press.

Rouffaer, G. P. (1980). Cab Sikureueng (Segel Sultan Aceh), (R. Sufi, Trans.) Proyek Rehabilitasi dan Perluasan Museum Daerah Istimewa Aceh, Banda Aceh.

Schrieke, B. (1955). Indonesian Sociological Studies, Part One, W. Van Hoeve Ltd-The Hague, Bandung.

Siegel, J. T. (1969). The Rope of God. Berkeley: University of California Press.

Tarling, N. (1969). British Policy in the Malay Peninsula and Archipelago: 1824-1871. Kuala Lumpur: Oxford University Press.

Teuku R. M. Ali bin Teuku Husin. (n. d). Silsilah Nasab dan Zurriat Uleebalang Lam Kabeu dan Sungai Iyu, [Lam Kabeu, Aceh Besar]. 